\title{
Late Pleistocene-Holocene sedimentary fluxes of organic carbon and biogenic silica in the northwestern Ross Sea, Antarctica
}

\author{
M. Frignani, ${ }^{1}$ F. Giglio, ${ }^{1}$ L. Langone, ${ }^{1}$ M. Ravaioli, ${ }^{1}$ A. Mangini ${ }^{2}$ \\ ${ }^{1}$ Istituto di Geologia Marina del C.NR, Via Gobetti 101, I-40129 Bologna, Italy \\ ${ }^{2}$ Institut für Umweltphysik, Universität Heidelberg, Im Neuenheimer Feld 366, D-6900 Heidelberg, Germany
}

\begin{abstract}
Eight sediment gravity cores, collected from the Joides and Drygalski basins, were analysed in order to understand late Pleistocene-Holocene biogenic flux changes in the Ross Sea, driven by paleoenvironmental changes. Core lithologies and magnetic-susceptibility depth profiles were used for core logging and stratigraphic correlation. Nineteen AMS radiocarbon dates of bulk organic matter were used to set chronological constraints and calculate sediment accumulation rates. These rates, which vary from $1.4-38 \mathrm{~cm} \mathrm{ka}^{-1}$, were used to obtain the burial fluxes of biogenic components. The highest fluxes occur in the deepest parts of the basins (TOC, $0.05-0.2 \mathrm{~g} \mathrm{~cm}^{-2} \mathrm{ka}^{-1}$; biogenic silica, $1.5-5 \mathrm{~g} \mathrm{~cm}^{-2} \mathrm{ka}^{-1}$ ), whereas topographic highs show the lowest values (TOC, $0.01-$ $0.1 \mathrm{~g} \mathrm{~cm}^{-2} \mathrm{ka}^{-1}$; biogenic silica, $0.1-1.4 \mathrm{~g} \mathrm{~cm}^{-2} \mathrm{ka}^{1}$ ). Dramatic changes in both physical properties and fluxes record the establishment of open marine-sedimentation conditions which occurred first in the Joides basin and then, with a delay of ca. 6000 years, in the Drygalski basin. Both TOC and biogenic-silica fluxes increase through the Holocene, though slightly differently. The high fluxes of both ${ }^{10} \mathrm{Be}$ and biogenic Ba suggest that sediment accumulation at basin sites is strongly influenced by lateral transport.
\end{abstract}

\section{INTRODUCTION}

High-latitude areas, such as the Antarctic continental margin, are amongst the most sensitive to climate changes because of their extreme environmental conditions. In the Antarctic marine environment, biogeochemical fluxes supply a significant part of the sedimentary material. The delivery of organic carbon and biogenic silica to the bottom mostly depends on primary productivity and preservation efficiency (DeMaster and others, 1996), which are a function of sea-ice extent and, therefore, of climate. In turn, changes in biogeochemical processes affecting the carbon balance in the upper water column of this region could significantly modify the level of atmospheric $\mathrm{CO}_{2}$ and potentially influence global climate. The record of past environmental changes, and their effects on oceanic biogeochemistry, is preserved in marine sediments (Domack and others, 1993; Frank, 1996; Frank and others, 1996) and can be used to reconstruct the response of the northwestern Ross Sea to natural global climate changes during the late Quaternary (Anderson and others, 1992; DeMaster and others, 1996; Licht and others, 1996; Brambati and others, 1997; Ceccaroni and others, in press). Our interest was mainly directed towards understanding sediment accumulation during the late Pleistocene and Holocene and to determining fluxes of organic carbon and biogenic silica and their variability as a function of environmental conditions. We addressed also the

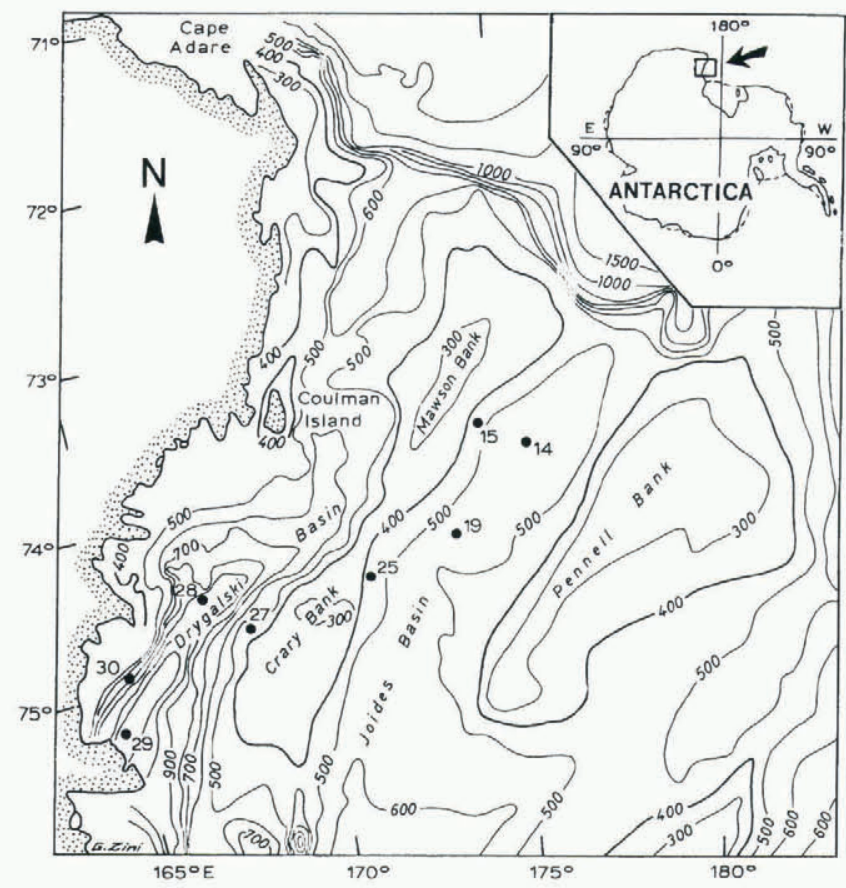

Fig. 1. Study area and sampling sites in the northwestern Ross Sea. Cores from the deepest areas of the basins are 14, 19, 28, 29 and 30 . Cores 15, 25, and 27 were retrieved from the flanks of Mawson and Crary banks. 
CORE 25

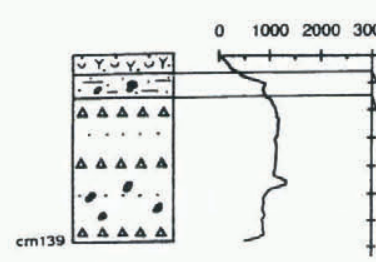

CORE 19

$0 \quad 100020003000$

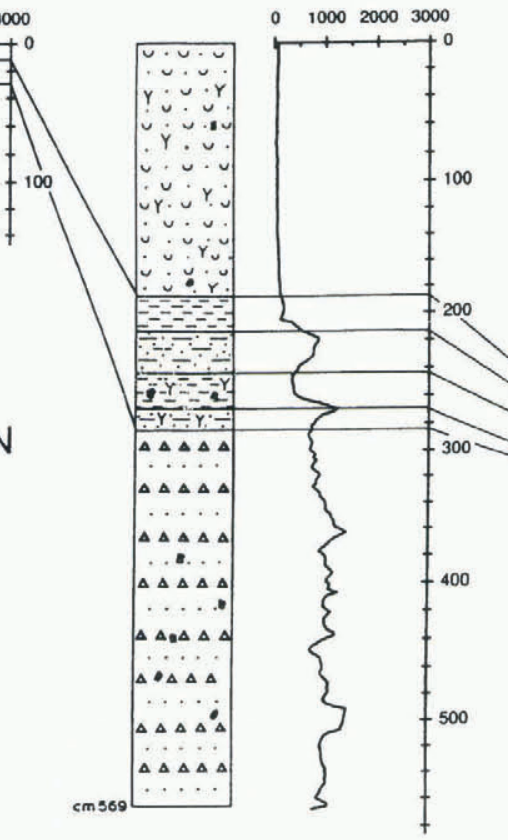

JOIDES BASIN

CORE 14

CORE 15

- 100020003000

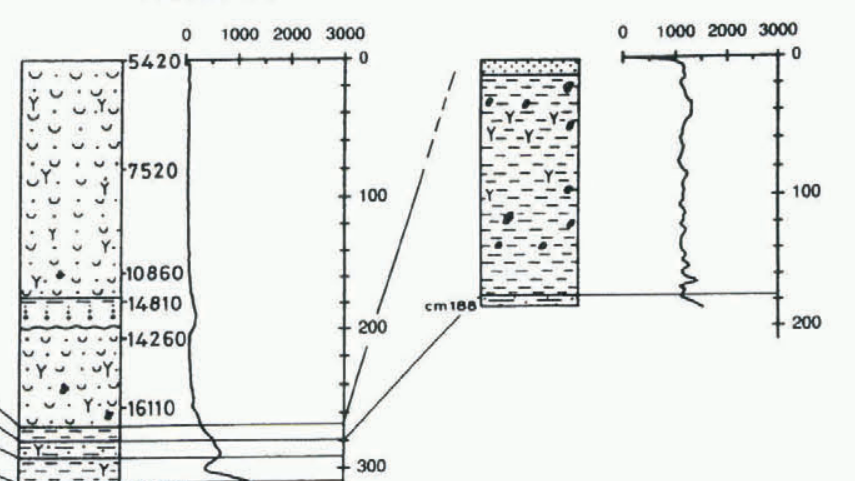

CORE 29

CORE 30

CORE 28

CORE 27

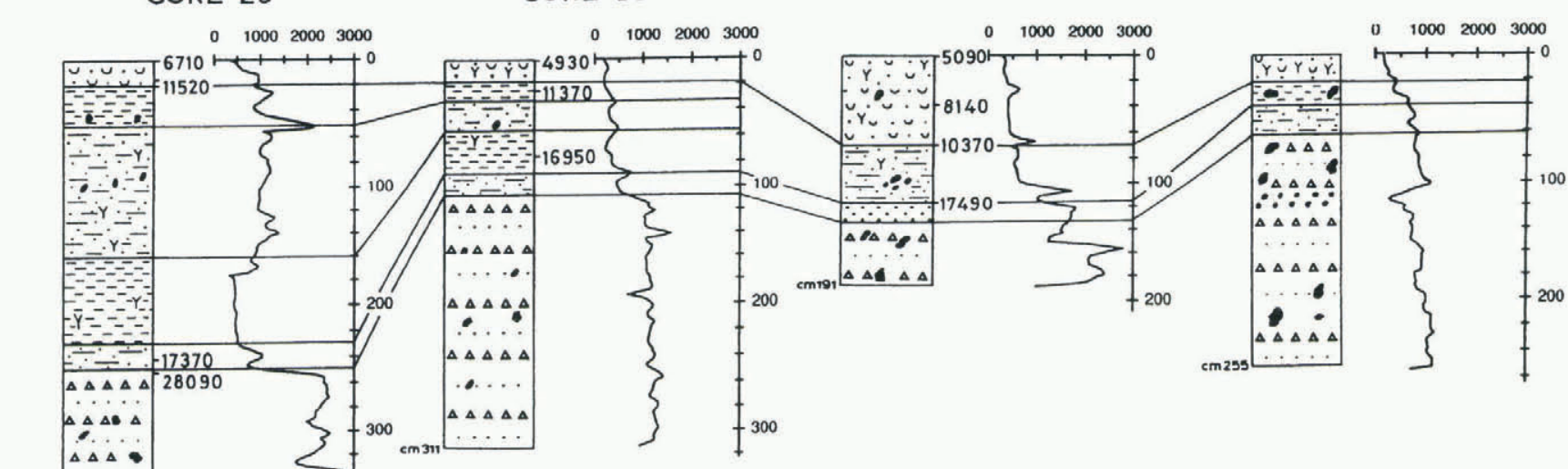

DRYGALSKI BASIN

Fig. 2. Lithological composition, magnetic-susceptibility-depth profiles, and core correlation. Conventional ${ }^{14}$ Cages (Stuiver and Pollach, 1977) are reported.

relative importance of vertical and lateral transport in the basins, and tried to estimate paleoproductivity using ${ }^{10} \mathrm{Be}$ and biogenic $\mathrm{Ba}$, respectively.

\section{MATERIALS AND METHODS}

In December 1990 and February 1991, eight sediment gravity cores were collected from the Joides and Drygalski basins in the northwestern Ross Sea. Core locations (Fig. 1) were selected in order to study sedimentary sequences in the two shelf basins and their margins. A comparison between gravity cores and box cores (Labbrozzi and others, in press) showed that gravity coring could cause the loss of $0-5 \mathrm{~cm}$ of top sediment. All cores were X-radiographed, scanned for magnetic susceptibility, opened and described. Samples were taken at selected depths, dried at $60^{\circ} \mathrm{C}$ and analysed for: (1) total organic carbon (TOC) and total nitrogen (N), using a CHN analyser after hydrochloric acid treatment; (2) biogenic silica, by the progressive-dissolution method (DeMaster, 1981); (3) Fe, Al, Ba and Mn by AAS after melting with $\mathrm{Li}$ metaborate and dissolution with $8 \mathrm{~N} \mathrm{HCl}$ (Frank, 1996); (4) uranium and thorium isotopes, from alpha counting after radiochemical separation and electrodeposition on stainless-steel disks (Frank, 1996); and (5) ${ }^{10}$ Be by AMS, carried out at the Institute Paul Scherrer, Zürich. Nineteen AMS radiocarbon dates, relative to different levels in four cores (14, 28, 29 and 30), were determined from bulk organic matter. Most analyses were carried out at the Antares Mass Spectrometry, Australian Nuclear Science \& Technology Organisation (ANSTO), whereas ${ }^{14} \mathrm{C}$ dates for core 30 were obtained from Brambati and others (1997). Porosities and dry bulk densities were calculated from the percentage water content (Berner, 1971) assuming a sediment density of $2.55 \mathrm{~g} \mathrm{~cm}^{-3}$. Biogenic-barium concentrations were calculated from the empirical formula suggested by Dymond 


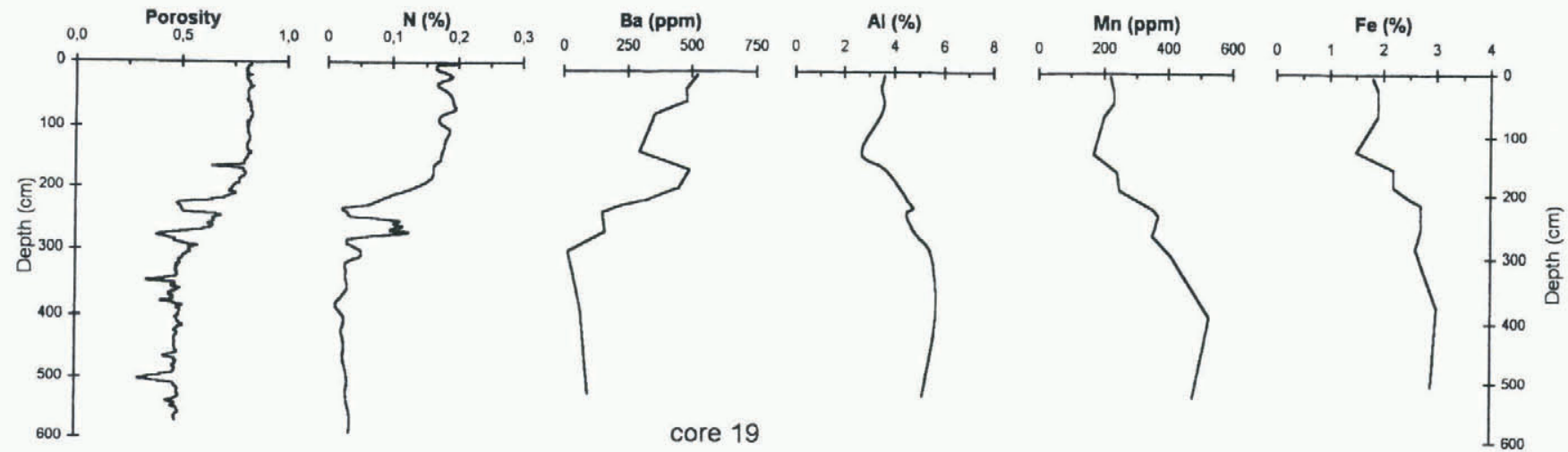

Fig. 3. Concentration-depth profiles of porosity, total $\mathcal{N}$, biogenic $\mathrm{Ba}, \mathrm{Al}, \mathrm{Mn}$ and Fe relative to core 19.

and others (1992): Biogenic $\mathrm{Ba}=$ Total $\mathrm{Ba}-(0.0075 \mathrm{Al})$, where $\mathrm{Al}$ is the aluminium concentration in the sample.

\section{RESULTS}

Core lithologies and depth profiles of magnetic susceptibilities are shown in Figure 2. The sedimentary sequence consists of three principal lithological units. The deeper one, massive and overconsolidated, is a diamicton (Cooper and Davey, 1987), which might represent basal till or glacial- marine sediment. This facies is characterised by high magnetic susceptibility and null, or low, content of biogenic components. Above the diamicton there are glacial-marine sediments, composed of muddy sand interbedded with mud and characterised by an upward increase of the biogenic components and a corresponding decrease of magnetic susceptibility. The uppermost unit is a biosiliceous mud, with a relatively high content of biogenic silica and TOC. In core 15 , from the flank of Mawson bank, this lithology is replaced by a sandy layer, which is a residual lag of previously depos-
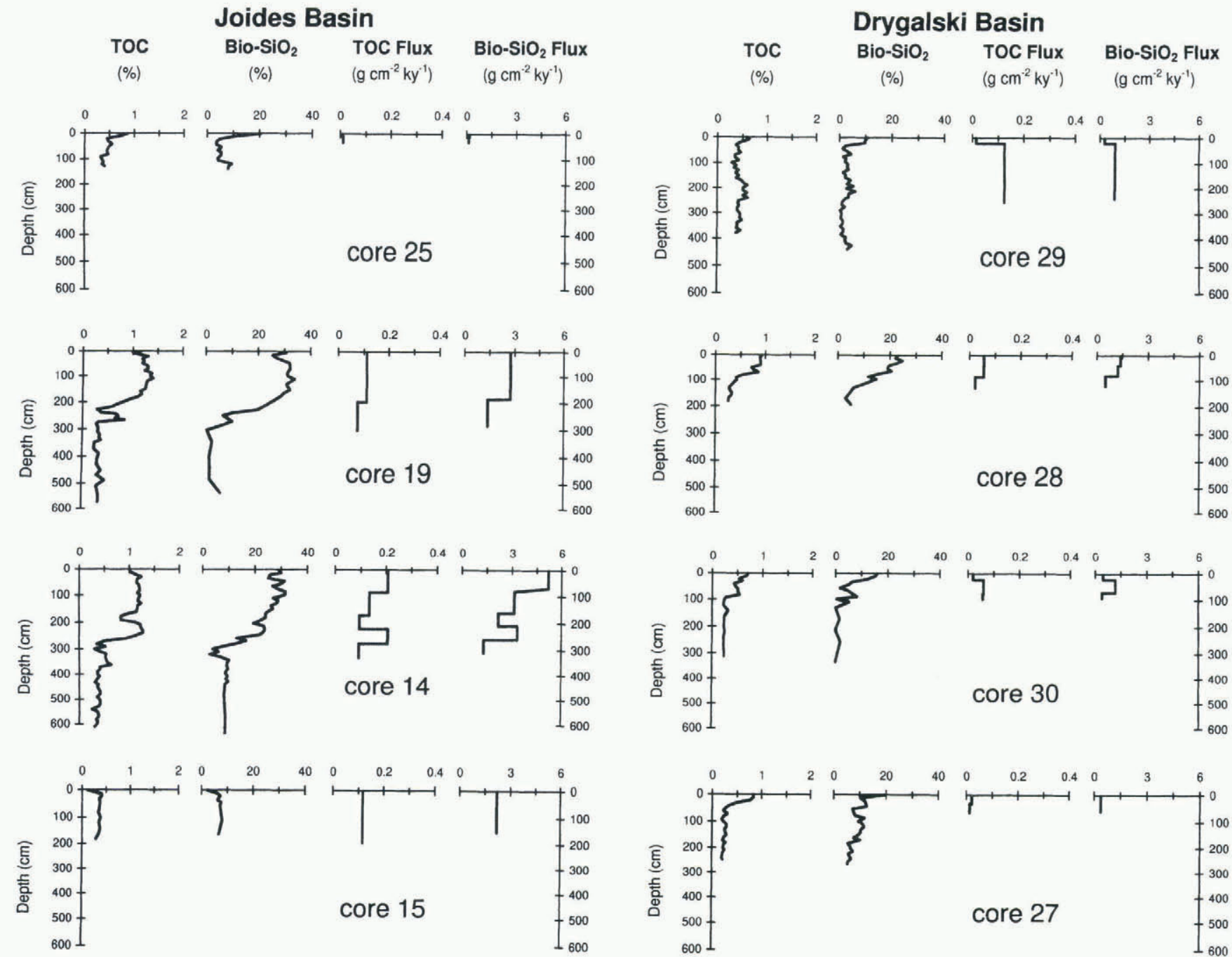

Fig. 4. Concentration-depth profiles and fluxes of organic carbon and biogenic silica. In most cases the distribution of total nitrogen (not shown) parallels that of organic carbon. 
ited glacial--marine sediment. Pebbles are found throughout the sediment column at all sites and represent the coarsest fraction of the continental input. According to the patterns shown in Figure 2, magnetic susceptibility is high in sediments with an important detrital component, and low where a significant fraction of the sediment is biogenic. In most cases magnetic-susceptibility profiles clearly show a variation from high values at depth to low values in the upper part of the core, marking the shift in sediment input during the retreat of the ice sheet. An exception is represented by core 15 .

Figure 3 shows concentration-depth profiles relative to core 19, as an example of the results obtained in this study. Concentrations of biogenic $\mathrm{Ba}, \mathrm{Al}, \mathrm{Fe}$, and $\mathrm{Mn}$ were measured only in samples from cores 19, 28 and 30. The depth distribution of $\mathrm{Al}$ and $\mathrm{Fe}$ concentrations are related to the abundance of the detritic component and show a correlation with magnetic susceptibility. Mn mostly behaves like $\mathrm{Al}$ and $\mathrm{Fe}$.

Figure 4 shows concentration-depth profiles of organic carbon and biogenic silica. In general, biogenic silica, organic carbon and total nitrogen content increase in recent times. The cores from the Joides basin show TOC, biogenic $\mathrm{Si}$ and biogenic $\mathrm{Ba}$ concentrations from 0.1 to $1.3 \%, 0$ to $35 \%$ and 18 to $520 \mu \mathrm{g} \mathrm{g}^{-1}$, respectively. In the Drygalski basin, closer to the land, values are lower: 0.2 to $0.9 \%, 2$ to $25 \%$ and 0 to $224 \mu \mathrm{g} \mathrm{g}^{-1}$, respectively.

\section{DISCUSSION}

\section{Sediment lithology and core correlation}

Based on lithologes, magnetic-susceptibility depth profiles and porosities, a core correlation is suggested which provides the chronostratigraphic framework (Fig. 2). The oldest units are diamictons, probably formed during the Last Glacial Maximum by the grounding ice sheet. Overconsolidation, absence of fossils and stratification, bad sorting and presence of reworked pebbles suggest a glacial origin as basal till (Kellogg and others, 1979; Anderson and others, 1980, 1984; Dunbar and others, 1985). However, the retrieval of well-preserved fossils at depths consistent with their age in core $19\left(19000{ }^{14} \mathrm{C}\right.$ years BP according to Brambati and others, 1996), suggests that the diamicton contains glacialmarine sediment. This sediment was deposited and then overconsolidated during phases of retreat and readvance of the grounding line during an overall phase of retreat. A similar pattern was proposed for another area of the Antarctic continental shelf by Gingele and others (1997). Above these sediments, a transitional unit corresponds to decoupling of the grounded ice (Kellogg and others, 1979). In this situation the glacial input is still present, but the sediment is enriched in marine-biogenic components. We have assumed that the most significant increase of biogenic silica and TOC content, with the deposition of biogenic mud and ooze, marks the onset of present conditions of a seasonally open sea. Low values of magnetic susceptibility are the result of lessened continental inputs. This facies is best represented by cores from the deepest zones of the basins, whereas present glacial-marine sediments closer to the coast are dominated by ice-rafted debris $(>20 \%)$ and terrigenous material (Dunbar and others, 1985).

A one year time series of current velocities was obtained for the northern part of Mawson Bank in 1995. The average current speed, measured by the bottom meter, was $30 \mathrm{~cm} \mathrm{~s}^{-1}$ with peaks of $55 \mathrm{~cm} \mathrm{~s}^{-1}$ (Picco and others, in press). These high currents winnow sediments previously deposited and prevent accumulation of newly formed biosiliceous mud. Core 15 represents this situation.

Table 1. Radiocarbon dates from the northwestern Ross Sea sediments. Errors are referred to $1 \sigma .{ }^{*}$ *) from Brambati and others (1997)

\begin{tabular}{|c|c|c|c|c|c|}
\hline $\begin{array}{l}\text { ANSTO } \\
\text { code }\end{array}$ & $\begin{array}{c}\text { Sample } \\
\text { depth }\end{array}$ & ${ }^{14}$ Cage & $\begin{array}{c}\text { A.NSTO } \\
\text { code }\end{array}$ & $\begin{array}{c}\text { Sample } \\
\text { depth }\end{array}$ & ${ }^{14}$ Cage \\
\hline & $\mathrm{cm}$ & years BP & & $\mathrm{cm}$ & years BP \\
\hline \multicolumn{3}{|c|}{ Drygalskibasin } & \multicolumn{3}{|c|}{ Joides basin } \\
\hline \multicolumn{3}{|c|}{ Core 28} & \multicolumn{3}{|c|}{ Core 14} \\
\hline OZB927 & $0-2$ & $5090 \pm 60$ & OZB931 & $0-2$ & $5420 \pm 50$ \\
\hline OZB928 & $40-42$ & $8140 \pm 250$ & OZB932 & $80-83$ & $7520 \pm 50$ \\
\hline OZB929 & $68-71$ & $10370 \pm 270$ & OZB933 & $160-163$ & $10860 \pm 120$ \\
\hline OZB930 & $110-114$ & $17490 \pm 930$ & OZB934 & $181-184$ & $14810 \pm 710$ \\
\hline \multicolumn{3}{|c|}{ Core 29} & OZB935 & $211-214$ & $14260 \pm 180$ \\
\hline OZB922 & $0-1$ & $6710 \pm 50$ & OZB936 & $259-261$ & $16110 \pm 240$ \\
\hline OZB923 & $19-21$ & $11520 \pm 60$ & OZB937 & $309-312$ & $24000 \pm 620$ \\
\hline OZB925 & $239-241$ & $17370 \pm 90$ & OZB938 & $360-363$ & $25090 \pm 860$ \\
\hline OZB926 & $249-251$ & $28090 \pm 290$ & & & \\
\hline \multicolumn{3}{|c|}{ Core 30} & & & \\
\hline$(*)$ & $0-2$ & $4930 \pm 40$ & & & \\
\hline$(*)$ & $22-24$ & $11370 \pm 50$ & & & \\
\hline (*) & $71.5-74$ & $16950 \pm 60$ & & & \\
\hline
\end{tabular}

\section{${ }^{14} \mathrm{C}$ chronology and accumulation rates}

Conventional ${ }^{14} \mathrm{C}$ ages (Stuiver and Pollach, 1977) are reported in Table 1 and Figure 2. The ${ }^{14} \mathrm{C}$ ages for the core top samples are $6710-4930{ }^{14} \mathrm{C}$ years BP. Such high values are not uncommon for Antarctic marine environments (Domack and others, 1989; Domack, 1992; DeMaster and others, 1996; Licht and others, 1996). In particular, the surface age of the organic carbon in Ross Sea sediments is typically $3000-2000{ }^{14} \mathrm{C}$ years BP, with older ages $\left(10000-5000{ }^{14} \mathrm{C}\right.$ years BP) in slowly accumulating slope deposits (DeMaster and others, 1996). Old surface ages may arise from several factors: (1) plankton growth in ${ }^{14} \mathrm{C}$-depleted waters; (2) loss of the core top during collection; (3) surficial sediment mixing; and (4) supply of reworked carbon (Domack and others, 1995). Because of uncertainties in the Antarctic reservoir effect and the difficulty in assessing the varying influence of the factors listed above, we chose not to correct our dates. Sediment accumulation rates were calculated assuming constant sedimentation between dated levels and the correlations shown in Figure 2 were used to obtain estimates for cores without ${ }^{14} \mathrm{C}$ data. When surface ${ }^{14} \mathrm{C}$ ages were lacking, rates were calculated using the surficial value of the closest core. The results are reported in Table 2. Accumulation rates reported by Kellogg and others (1979), Hilfinger (1995) and Franceschini (1995) for sediments of the southwestern Ross Sea and the Joides basin vary from $3-10 \mathrm{~cm} \mathrm{ka}^{-1}$. According to DeMaster and others (1996), sediments in this area accumulate at rates of $0-250 \mathrm{~cm} \mathrm{ka}^{-1}$, with an average value of $7.4 \mathrm{~cm} \mathrm{ka}^{-1}$. Our values agree with those reported by other authors, and confirm high heterogeneity of sedimentation processes on the shelf in relation to location and topography. 
Table 2. Sediment accumulation rates calculated on the basis of ${ }^{14}$ Cages and core correlation

\begin{tabular}{|c|c|c|c|}
\hline Depth & $\begin{array}{c}\text { Accumulation } \\
\text { rate }\end{array}$ & Depth & $\begin{array}{c}\text { Accumulation } \\
\text { rate }\end{array}$ \\
\hline $\mathrm{cm}$ & $\mathrm{cm} \mathrm{ka}^{-1}$ & $\mathrm{~cm}$ & $\mathrm{~cm} \mathrm{ka}^{-1}$ \\
\hline \multirow{2}{*}{\multicolumn{2}{|c|}{$\begin{array}{c}\text { Drygalskibasin } \\
\text { Core } 29\end{array}$}} & \multicolumn{2}{|c|}{ joides basin } \\
\hline & & \multicolumn{2}{|c|}{ Core 25} \\
\hline $0-20$ & 4.1 & $0-15$ & 1.5 \\
\hline $20-240$ & 37.6 & $15-30$ & 1.8 \\
\hline \multicolumn{2}{|c|}{ Core 30} & \multicolumn{2}{|c|}{ Core 19} \\
\hline $0-23$ & 3.4 & $0-195$ & 18.0 \\
\hline $23-72.75$ & 8.9 & $195-291$ & 12.4 \\
\hline \multicolumn{2}{|c|}{ Core 28} & \multicolumn{2}{|c|}{ Core 14} \\
\hline $0-41$ & 13.4 & $0-81.5$ & 38.4 \\
\hline $41-70.5$ & 13.2 & $81.5-161.5$ & 24.0 \\
\hline $70.5-110$ & 5.6 & $161.5-212.5$ & 15.1 \\
\hline \multicolumn{2}{|c|}{ Core 27} & $212.5-260$ & 25.4 \\
\hline $0-20$ & 3.8 & $260-310.5$ & 16.3 \\
\hline $20-42$ & 3.1 & & \\
\hline
\end{tabular}

In the Joides basin, sediment accumulation rates vary from $<1$ to $38 \mathrm{~cm} \mathrm{ka}^{-1}$. The highest values characterise modern sediment in the deepest part of the basin and decrease down-core, with the exception of the interval between 270 and $320 \mathrm{~cm}$ at site 14 . On the other hand, modern sediment accumulation is slow (core 25) or null (core 15) along the southeastern flanks of Mawson bank and Crary bank. Although sediment accumulation at site 25 was also limited under glacial-marine conditions, at site 15 the glacial-marine unit appears relatively expanded (Fig. 2) and the accumulation rate could have been very high. This would be consistent with the seismic records, which indicate that thick packages of material were deposited on the sides of the troughs during the deglaciation (Shipp and Anderson, 1994).

In core 14, between 205 and $175 \mathrm{~cm}$ depth, a turbiditic event is recorded. This layer consists of graded sand and is characterised by an erosive contact at the base and by a faint lamination in the upper part. The hypothesis that it represents a turbidite is also supported by the features shown in most profiles and by the inversion of the ${ }^{14} \mathrm{C}$ age at $181-184 \mathrm{~cm}$ depth.

In the Drygalski basin, sediment accumulation rates range from 4 to $38 \mathrm{~cm} \mathrm{ka}^{-1}$. Here the most recent accumulation rates are low compared with those calculated for the Joides basin and high rates characterise the deposition of glacial-marine sediments in cores 29 and 30. On the other hand, sediments at depth in cores 27 and 28 were deposited very slowly. In this basin, the patterns show two different trends: (1) in the northern area (core 28) accumulation rates increased with time, starting with the beginning of marine biogenic sedimentation; (2) at sites 29 and 30, close to the Drygalski Ice Tongue, glacial-marine sediments accumulated at high rates. This is probably the result of the high input of sediment from the melting of basal ice of the retreating ice tongue. Core 27, from the northwestern flank of the Crary bank, shows low sediment-accumulation rates and minor variations with time.

\section{Biogenic fluxes}

Dry bulk densities were used to calculate sediment accumulation rates, which were combined with concentrations of TOC and biogenic silica to obtain the burial fluxes of the biogenic components. The temporal changes of the fluxes, which are mainly related to the patterns of accumulation rates, is shown in Figure 4. The highest present-day fluxes occur in the deepest parts of the basins (TOC, $0.05-0.2 \mathrm{~g} \mathrm{~cm}^{-2} \mathrm{ka}^{-1}$; biogenic silica, $1.5-5 \mathrm{~g} \mathrm{~cm}^{-2} \mathrm{ka}^{-1}$ ), whereas topographic highs show the lowest values (TOC, $0.01-0.1 \mathrm{~g} \mathrm{~cm}^{-2} \mathrm{ka}^{-1}$; biogenic silica, $\left.0.1-1.4 \mathrm{~g} \mathrm{~cm}^{-2} \mathrm{ka}^{-1}\right)$. In most cases, fluxes change dramatically with the establishment of open marine sedimentation. This change occurred at different times in the two basins, first in the Joides and then, after a delay of about 6000 years, in the Drygalski (Figs 2 and 4). With eight dated levels, we achieved the most detailed chronology and flux history for core 14 (Joides basin). Here, a trend is clearly observed in that both TOC and biogenic-silica fluxes increase during the Holocene, though slightly differently. For example, in the uppermost $80 \mathrm{~cm}\left(7520 \pm 50\right.$ uncorrected ${ }^{14} \mathrm{C}$ years BP $)$ opal concentration and flux increase more than organiccarbon ones (Fig. 4).

\section{Vertical and lateral components of fluxes}

Recently, Jaeger and others (1996) addressed the influence of the lateral advection of particles in decoupling the processes in surface waters from the underlying sea bed. François and others (1995) and Kumar (1994) showed that the lateral component of sedimentation can be as much as ten times greater than the vertical contribution. In certain cases, it is possible to estimate the contribution of lateral advection with respect to vertical deposition using ${ }^{230} \mathrm{Th}$ inventories (Frank and others, 1996). However, this method is difficult to apply in these conditions since the generally low water-column depth provides low excess ${ }^{230} \mathrm{Th}$ to the sediments. Furthermore, a process of authigenic-uranium enrichment is indicated by the ratios of ${ }^{230} \mathrm{Th} /{ }^{234} \mathrm{U}$ and ${ }^{238} \mathrm{U} /{ }^{232} \mathrm{Th}$. The former is low and the latter, which should be close to 0.25 in marine sediment (unpublished data from A. Mangini), is well above this value in core 19 in most cases, ranging between 0.4 and 0.7 down to $180 \mathrm{~cm}$ depth.

In an effort to evaluate the relationship between productivity and sedimentary fluxes, the natural isotope ${ }^{10} \mathrm{Be}$ was determined. It is known that biogeochemical processes in the water column play a major role in the transfer to the sediments of ${ }^{10} \mathrm{Be}$ produced in the atmosphere by cosmic radiation. Because of its relatively long residence time in the water, an efficient transfer occurs in areas of high productivity or particle input (Rutsch and others, 1995). Fluxes of ${ }^{10} \mathrm{Be}$ at station 19 vary between $5 \times 10^{9}$ and $12 \times 10^{9}$ atoms $\mathrm{cm}^{-2} \mathrm{a}^{-1}$ from late Pleistocene to Holocene. Assuming that the system is in a steady state, the atmospheric production $\left(1.21 \pm 0.26 \times 10^{9}\right.$ atoms $\left.\mathrm{cm}^{-2} \mathrm{a}^{-1}\right)$ should equal the downward flux. Measured fluxes largely exceed (even by 8 times) the expected ones. The enrichment of ${ }^{10} \mathrm{Be}$ in these sediments relative to the atmospheric input can be explained by a significant contribution of sediment from nearby areas due to lateral advection and focusing. ${ }^{210} \mathrm{~Pb}$ inventories and fluxes can be used in the same way. Although previous data suggested that rain rates account for most of the material accumulating in the deepest part of the basins (Langone and others, in press), other evidence now confirms that sediment focusing can be a very important sedimentary process for basin areas (Labbrozzi and others, in press).

While minimum values of TOC and biogenic-silica 
fluxes are similar in the two areas, the highest fluxes characterise the Joides basin. These differences are difficult to explain on the basis of present knowledge and could be an artefact due to a different incidence of sediment focusing.

\section{Productivity and paleoproductivity}

Burial rates of TOC and biogenic silica depend on the amount of material produced in the euphotic zone and that transported laterally. Our results show these rates are particularly high in the Joides basin. A tentative estimate of export paleoproductivity was carried out according to François and others (1995) and Nürnberg and others (1997): biogenic $\mathrm{Ba}$ concentrations and fluxes were calculated for cores 19 and 28. Fluxes vary from 5 to $60 \mathrm{gCm}^{-2} \mathrm{a}^{-1}$, and are higher in the Drygalski than the Joides basin. These values are in agreement with the integrated shelf-wide export productivity of $16 \mathrm{gC} \mathrm{m}^{-2} \mathrm{a}^{-1}$ estimated by Nelson and others (1996) for the Ross Sea. According to uranium and Mn data, however, these cores could be anoxic or suboxic and calculated biogenic Ba may not be a suitable paleoproductivity proxy, due to possible diagenetic remobilisation (Dymond and others, 1992). Because of this, barium-derived biogenic fluxes are likely underestimated. On the other hand, the increase of biogenic $\mathrm{Ba}$ flux in core 19 at the onset of the open marine sedimentation, which parallels the increase of the ${ }^{10} \mathrm{Be}$ flux, might reflect increased focusing rather than simply an increase of biogenic production in overlying waters.

\section{CONCLUSIONS}

(1) The sediment sequence in cores from the Joides and Drygalski basins consists of three principal lithological units. From past to present they are: basal tills, glacial-marine sediments and biogenic mud and ooze.

(2) Maximum concentrations of biogenic components (organic carbon $>1 \%$ and biogenic silica $>30 \%$ ) were found in the deepest zones of the basins, whereas the lowest contents were found in cores from topographic highs.

(3) Maximum accumulation rates during the Holocene vary between $38 \mathrm{~cm} \mathrm{ka}^{-1}$ in the central part of the Joides basin and $1.4 \mathrm{~cm} \mathrm{ka}^{-1}$ on the banks. Burial fluxes of biogenic components follow the same pattern: basins accumulate faster (TOC, $0.05-0.2 \mathrm{~g} \mathrm{~cm}^{-2} \mathrm{ka}^{-1}$; biogenic silica, $1.5-5 \mathrm{~g}$ $\mathrm{cm}^{-2} \mathrm{ka}^{-1}$ ) than banks (TOC, $0.01-0.1 \mathrm{~g} \mathrm{~cm}^{-2} \mathrm{ka}^{-1}$; biogenic silica, $\left.0.1-1.4 \mathrm{~g} \mathrm{~cm}^{-2} \mathrm{ka}^{-1}\right)$.

(4) Depth profiles of both physical properties and fluxes record a dramatic change corresponding to the establishment of conditions of seasonally open marine sedimentation. This change occurred first in the Joides basin and then, with a delay of ca. 6000 years, in the Drygalski basin.

(5) ${ }^{10} \mathrm{Be}$ was used to estimate the relative importance of lateral transport and vertical sinking. Results from cores 19 and 28 show the flux is up to eight times that expected, suggesting that focusing is a very significant processes in basin areas. Also, biogenic Ba fluxes seem dominated by lateral advection. for the different accumulation of biogenic material in the two basins.

\section{ACKNOWLEDGEMENTS}

This research was carried out within the framework of the projects "Ecology and Biogeochemistry of the Southern Ocean" and "Glaciology and Paleoclimatology" of the Italian Programma Nazionale di Ricerche in Antartide, and supported financially by the Ente Nazionale Energia e Ambiente. The authors wish to thank L. Labbrozzi, E. Lipparini, G. Rovatti, G. Marozzi, and V. Palumbo who helped in the sampling operation and/or carried out analytical work. Special thanks are extended to P. Sedwick who reviewed the paper and provided invaluable comments and suggestions. The drawings were provided by G. Zini. This is contribution No. 1128 from the Istituto di Geologia Marina, Consiglio Nazionale delle Ricerche, Bologna.

\section{REFERENGES}

Anderson, J. B., D. D. Kurtz, E.W. Domack and K. M. Balshaw. 1980. Glacial and glacial marine sediments of the Antarctic continental shelf. J. Geol., 88(4), 399-414.

Anderson, J. B., C. F. Brake and N. C. Myers. 1984. Sedimentation on the Ross Sea continental shelf, Antarctica. Mar. Geol., 57(1-4), 295-333.

Anderson, J. B., S. S. Shipp, L. R. Bartek and D. E. Reid. 1992. Evidence for a grounded ice sheet on the Ross Sea continental shelf during the Late Pleistocene and preliminary paleodrainage reconstruction. In Elliot, D. H., ed. Contributions to Antarctic research III. Washington, DC, American Geophysical Union, 39-62. (Antarctic Research Series 57.)

Berner, R. A. 1971. Principles of chemical sedimentology. New York, McGraw-Hill.

Brambati, A. and 6 others. 1996. Some paleoecological remarks on the Ross Sea shelf, Antarctica. In International Workshop "Ross Sea Ecology", 14-16 May 1996, Taormina. Proceedings. Genova, CoNISMa, 113-115.

Brambati, A. and 6 others. 1997. Paleoenvironmental record in core ANTA9130 (Drygalski Basin, Ross Sea, Antarctica). In Barker, P. F. and A. K. Cooper, eds. Geology and seismic stratigraphy of the Antarctic margin 2. Washington, DC, American Geophysical Union, 137-151. (Antarctic Research Series 71.)

Ceccaroni, L., M. Frank, M. Frignani, L. Langone, M. Ravaioli and A. Mangini. In press. Late Quaternary fluctuations of biogenic component fluxes on the continental slope of the Ross Sea, Antarctica. 7. Mar. Syst.

Davey, F. J. 1987. Geology and structure of the Ross Sea region. In Cooper, A. and F. J. Davey, eds. The Antarctic continental margin: geology and geophysic. of the western Ross Sea. Houston, TX, Circum-Pacific Council for Energy and Mineral Resources, 1-15. (CPCEMR Earth Science Series 5B,

DeMaster, D. J. 1981. The supply and accumulation of silica in the marine environment. Geochim. Cosmochim. Acta, 45, 1715-1732.

DeMaster, D. J., O. Ragueneau and C. A. Nittrouer. 1996. Preservation efficiencies and accumulation rates for biogenic silica and organic $\mathrm{C}, \mathrm{N}$ and $\mathrm{P}$ in high-latitude sediments: the Ross Sea. 7. Geophys. Res., 101 (C8), $18,501-18,518$.

Domack, E.W. 1992. Modern carbon-14 ages and reservoir corrections for the Antarctic Peninsula and Gerlache Strait area. Antarct. F. U.S., 27 (5), 63-64.

Domack, E. W., T. A. Mashiotta, L. A. Burkley and S. E. Ishman. 1993. 300year cyclicity in organic matter preservation in Antarctic fjord sediments. In Kennett, J. P. and D. A. Warnke, eds. The Antarctic paleoenvironment: a perspective on global change. Washington, DC, American Geophysical Union, 265-272. (Antarctic Research Series 60.)

Domack, E.W., S. E. Ishman, A. B. Stein, C. E. McClellen and A. J. T. Jull. 1995. Late Holocene advance of the Müller Ice Shelf, Antarctic Peninsula: sedimentological, geochemical and palaeontological evidence. Antart. Sci., 7 (2), 159-170.

Domack, E.W., A. J. T. Jull, J. B. Anderson, T.W. Linick and C. R. Williams. 1989. Application of tandem accelerator mass-spectrometer dating to Late Pleistocene-Holocene sediments of the East Antarctic continental shelf. Quat. Res., 31 (2), 277-287.

Dunbar, R. B., J. B. Anderson and E.W. Domack. 1985. Oceanographic influences on sedimentation along the Antarctic continental shelf. In Jacobs, S. S., ed. Oceanology of the Antarctic continental shelf. Washington, DC, American Geophysical Union, 291-312. (Antarctic Research Series 43.) 
Dymond, J., E. Suess and M. Lyle. 1992. Barium in deep-sea sediment: a geochemical proxy for paleoproductivity. Paleoceanography, 7 (2), 163-181.

Franceschini, J. 1995. Preservation of total organic carbon in sediments from the Ross Sea, Antarctica. (Ph.D. thesis, Hamilton College, Clinton, NY.)

François, R., S. Honjo, S. T. Manganini and G. E. Ravizza. 1995. Biogenic barium fluxes to deep sea: implications for paleoproductivity reconstruction. Global Biogeochem. Cycles, 9(2), 289-303.

Frank, M. 1996. Reconstruction of Late Quaternary environmental conditions applying the natural radionuclides ${ }^{230} \mathrm{Th},{ }^{10} \mathrm{Be},{ }^{231} \mathrm{~Pa}$ and ${ }^{238} \mathrm{U}$. A study of deep sea sediments from the eastern sector of the Antarctic circumpolar current system. Ber. Polarforsch. 186.

Frank, M., R. Gersonde, M. Rutgers van der Loeff, G. Kuhn and A. Mangini. 1996. Late Quaternary sediment dating and quantification of lateral sediment redistribution applying ${ }^{230} \mathrm{Th}_{\mathrm{ex}}$ : a study from the eastern Atlantic sector of the Southern Ocean. Geol. Rundsch., 85, 554-566.

Gingele, F. X., G. Kuhn, B. Maus, M. Melles and T. Schöne. 1997. Holocene ice retreat from the Lazarev Sea shelf, East Antarctica. Continental Shelf Res., $17(2), 137-163$.

Hilfinger, M. 1995. Chronology of the Late Pleistocene-Holocene deglaciation in the Ross Sea. (Ph.D. thesis, Hamilton College, Clinton, NY.)

Jaeger, J. M., C. A. Nittrouer, D. J. DeMaster, C. Kelchner and R. B. Dunbar. 1996. Lateral transport of settling particles in the Ross Sea and implications for the fate of biogenic material. 7. Geophys. Res., 101 (C8), 18,478-18,488

Kellogg, T. B., R. S. Truesdale and L. E. Osterman. 1979. Late Quaternary extent of the West Antarctic ice sheet: new evidence from Ross Sea cores. Geolog), 7(5), 249-253.

Kumar, M. 1994. Trace metals and natural radionuclides as tracers of ocean productivity. (Ph.D. thesis, Columbia University.)

Labbrozzi, L., L. Langone, M. Frignani and M. Ravaioli. In press. Burial rates for biogenic silica, organic $\mathrm{C}$ and $\mathrm{N}$ at three sites of the Ross Sea (Antarctica). In XII National Congress AIOL, 18-21 September 1996, Vulcano Island. Proceedings. Genova, Associazione Italiana di Oceanologia e Limnologia.

Langone, L., M. Frignani, L. Labbrozzi and M. Ravaioli. In press. Present day biosiliceous sedimentation in the NW Ross Sea (Antarctica). 7. Mar. Syst.

Licht, K. J., A. E. Jennings, J. T. Andrews and K. M. Williams. 1996. Chronology of the late Wisconsin ice retreat from the western Ross Sea, Antarctica. Geology, 24(3), 223-226.

Nelson, D. M., D. J. DeMaster, R. B. Dunbar and W. O. Smith, Jr. 1996. Cycling of organic carbon and biogenic silica in the Southern Ocean: large-scale estimates of water-column and sedimentary fluxes in the Ross Sea. 7. Geophys. Res., 101 (C8), 18,519-18,532.

Nürnberg, C. C., G. Bohrmann, M. Schlüter and M. Frank. 1997. Barium accumulation in the Atlantic sector of the Southern Ocean: results from 190,000-year records. Paleoceanography, 12 (4), 594-603.

Picco, P., A. Bergamasco, L. Demicheli, L. Langone, G. M. R. Manzella and R. Meloni. In press. Current, temperature and salinity measurements in the Ross Sea shelf (Antarctica) during 1995/1996: data presentation. In XII National Congress AIOL, 18-21 September 1996, Vulcano Island. Proceedings. Genova, Associazione Italiana di Oceanologia e Limnologia.

Rutsch, H.-J. and 6 others. $1995 .{ }^{10} \mathrm{Be}$ and Ba concentrations in West African sediments trace productivity in the past. Earth Planet. Sci. Lett., 133(1-2), $129-143$.

Shipp, S. S. and J. B. Anderson. 1994. High-resolution seismic survey of the Ross Sea continental shelf: implications for ice-sheet retreat behavior. Antarct. J. U.S., 29 (5), Review 1994, 137-138.

Stuiver, M. and H. A. Polach. 1977. Discussion: reporting of ${ }^{14} \mathrm{C}$ data. Radiocarbon, 19 (3), 355-363. 